\title{
Effects of Nitrogen Deposition on an Arid Grassland in the Colorado Plateau Cold Desert
}

\author{
Susanne Schwinning, ${ }^{1}$ Benjamin I. Starr, ${ }^{2}$ Nathan J. Wojcik, ${ }^{3}$ \\ Mark E. Miller, ${ }^{4}$ James E. Ehleringer, ${ }^{5}$ and Robert L. Sanford Jr. ${ }^{6}$ \\ Authors are ${ }^{1}$ Assistant Professor, Biology Department, Texas State University, San Marcos, TX 78666; ${ }^{2}$ Research Technician, \\ Department of Biology, University of Utah, Salt Lake City, UT 84112; ${ }^{3}$ Doctoral Student, Biological Science, \\ University of Denver, Denver, CO 80208; ${ }^{4}$ Ecologist, U.S. Geological Service, 2290 S. Resource Blvd, Moab, UT 84532; \\ ${ }^{5}$ Distinguished Professor, Department of Biology, University of Utah, Salt Lake City, UT 84112; and \\ ${ }^{6}$ Professor, Biological Science, University of Denver, Denver, CO 80208.
}

\begin{abstract}
Historically, ecosystems in the southwestern United States derived much of their nitrogen (N) from N-fixation in biological soil crusts. Today, these regions have highly reduced crust cover, and atmospheric deposition may be the dominant source of $\mathrm{N}$. This study investigates the effects of increased nitrogen deposition on nitrogen uptake, photosynthesis, and growth of the two main forage grasses on the Colorado Plateau, galleta (Hilaria jamesii [Torr.] Benth.) and Indian ricegrass (Oryzopsis hymenoides, [Roemer \& J.S. Schultes] Ricker ex Piper). Plots were fertilized for 2 years with 0, 10, 20, and $40 \mathrm{~kg}$ nitrogen ha $^{-1}$ annually, up to $4 \times$ the estimated current annual deposition rate, in 2 applications per year (spring and summer). Half-plots were fertilized with either $\left(\mathrm{NH}_{4}\right)_{2} \mathrm{SO}_{4}$ in $\mathrm{KCl}$ solution or with $\mathrm{KNO}_{3}$ solution to determine possible differences in the effects of $\mathrm{NH}_{4}^{+}$and $\mathrm{NO}_{3}{ }^{-}$in this system. Neither grass increased leaf photosynthesis or tiller size due to supplemental N. Galleta also did not increase tiller density, while estimated live tiller density in Indian ricegrass increased up to $50 \%$ in the second year. Nitrogen applications accelerated the onset of water stress in both species presumably through stimulating ecosystem transpiration. Nitrogen form did not significantly affect any aspect of grass physiological performance or growth. However, leaf nitrogen in $\mathrm{NH}_{4}{ }^{+}-$fertilized plants was significantly more isotopically enriched than in $\mathrm{NO}_{3}{ }^{-}$-fertilized plants, suggesting that both species incorporated $\mathrm{NH}_{4}-\mathrm{N}$ only after it had been enriched by soil turnover. Seedlings of Russian Thistle (Salsola iberica, Sennen \& Pau), a noxious annual invasive weed on western rangelands, grew rapidly in the first summer on plots with $40 \mathrm{~kg}_{\text {nitrogen ha }}^{-1}$ per annum, and more so on plots fertilized with $\mathrm{NO}_{3}{ }^{-}$than with $\mathrm{NH}_{4}{ }^{+}$. The study suggests that changes in the timing and amount of nitrogen input may alter community composition through facilitating the invasions of summer-active noxious weeds.
\end{abstract}

\section{Resumen}

Históricamente, los ecosistemas del sudoeste del EE.UU. obtuvieron mucho de su nitrógeno (N) de la fijación de N en las costras biológicas del suelo, hoy, estas regiones han reducido grandemente la cobertura de estas costras y la deposición atmosférica puede ser la fuente dominante de N. Este estudio investiga los efectos del aumento de la deposición de N en la absorción de N, fotosíntesis y crecimiento de dos principales zacates forrajeros del la Planicie del Colorado, "Galleta" (Hilaria jamesii [Torr.] Benth.) e "Indian ricegrass" (Oryzopsis hymenoides, [Roemer \& J.S. Schultes] Ricker ex Piper). Las parcelas fueron fertilizadas por 2 años con $0,10,20$ y $40 \mathrm{~kg} \mathrm{~N} \mathrm{ha}^{-1}$ anuales hasta tener 4 veces la tasa anual actual estimada de deposición y aplicación se realizó en 2 eventos por año (primavera y verano). La mitad de las parcelas fueron fertilizadas con $\left(\mathrm{NH}_{4}\right)_{2} \mathrm{SO}_{4}$ en solución de

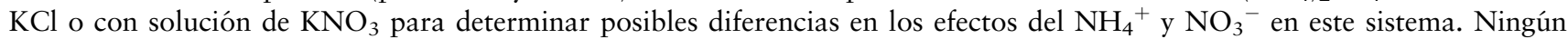
zacate incrementó la fotosíntesis de las hojas o el tamaño de los hijuelos debido al N suplementario. El zacate "Galleta" tampoco incrementó su densidad de hijuelos, mientras que la densidad estimada de hijuelos vivos del "Indian ricegrass" aumentó hasta $50 \%$ en el segundo año. Las aplicaciones de $\mathrm{N}$ aceleraron el inicio del estrés de agua en ambas especies, presumiblemente a través de estimular la transpiración del ecosistema. La forma del $\mathrm{N}$ no afectó significativamente ninguno de los aspectos del comportamiento fisiológico de los zacates o del crecimiento. Sin embargo, en $\mathrm{N}$ de las hojas en las plantas fertilizadas con $\mathrm{NH}_{4}{ }^{+}$ fue significativamente más isotópicamente enriquecido que en las plantas fertilizadas con $\mathrm{NO}_{3}{ }^{-}$, sugiriendo que ambas especies incorporaron $\mathrm{NH}_{4}-\mathrm{N}$ solo después de que habían sido enriquecidas por las aportaciones del suelo. Plántulas de "Russian Thistle" (Salsola iberica, Sennen \& Pau), una planta anual, nociva e invasora de los pastizales del oeste, creció rápidamente en el primer verano en las parcelas con $40 \mathrm{~kg} \mathrm{~N} \mathrm{ha}^{-1} \cdot$ año ${ }^{-1}$ y más en las parcelas fertilizadas con $\mathrm{NO}_{3}{ }^{-}$que en las fertilizadas con $\mathrm{NH}_{4}{ }^{+}$. Este estudio sugiere que cambios en la época y cantidad de entrada de $\mathrm{N}$ puede alterar la composición de la comunidad a través de facilitar las invasiones de las malezas nocivas activas en verano.

Key Words: native grasses, biological crust, invasion, timing of nitrogen input

Research was funded by the Environmental Protection Agency and National Park Service through the PRIMENet program. Jayne Belnap provided valued advice throughout the experiment and on the manuscript.

At the time of the research, the senior author was postdoctoral associate in the Biology Department, University of Utah, Salt Lake City.

Correspondence: Susan Schwinning, 601 University Drive, Biology Dept, Texas State University, San Marcos, TX 78666. Email: schwinn@txstate.edu

Manuscript received 16 November 2003; manuscript accepted 20 June 2005. 


\section{INTRODUCTION}

Historically, arid systems in the western United States are believed to have derived much of their nitrogen $(\mathrm{N})$ from $\mathrm{N}$ fixing components of the biological soil crusts (Belnap 2003). These crusts, which are comprised of complex associations of cyanobacteria, lichens, mosses, algae, and fungi, are extremely sensitive to compaction caused by trampling (Evans and Belnap 1999). Today, many arid rangelands have highly reduced crust cover, and another source of $\mathrm{N}$, atmospheric deposition, is equaling or exceeding the magnitude of $\mathrm{N}$ inputs from biological N-fixation in soil crusts (Vitousek et al. 1997; Belnap 2003). Nitrogen inputs have detrimental effects on N-fixing crust organisms such as cyanolichens (Nash and Sigal 1999), so that the $\mathrm{N}$ cycle of arid ecosystems may be permanently altered, depending on inputs, by biological $\mathrm{N}$ fixation to atmospheric deposition. Globally, atmospheric $\mathrm{N}$ deposition has increased sharply since the 1950s, and average deposition rates are estimated at $10 \mathrm{~g} \mathrm{~N} \mathrm{~m}^{-2}$ per year and rising, although there is large regional variation (Vitousek et al. 1997). The consequences of this shift in the dominant source and type of ecosystem $\mathrm{N}$ input in arid regions are largely unknown.

The productivity of arid and semiarid rangelands is strongly tied to the availability of water, but $\mathrm{N}$ is an important secondary factor limiting primary productivity (Hooper and Johnson 1999; Ehleringer 2001). Large variation among species in the degree of their individual responses to $\mathrm{N}$ fertilization is possible (Lowe et al. 2002). Individual differences in species responses to changing $\mathrm{N}$ fertilization, some related to photosynthetic pathway, can shift community composition, especially in grasslands (Brown 1978; Sage and Pearcy 1987; Wedin and Tilman 1996). For example, increased levels of $\mathrm{N}$ deposition could lessen the dominance of $\mathrm{C}_{4}$ species compared to $\mathrm{C}_{3}$ species, by offsetting the superior $\mathrm{N}$ use efficiency of $\mathrm{C}_{4}$ species (Sage and Kubien 2003). Increases in soil $\mathrm{N}$ can also increase the dominance of invasive alien plants, particularly if accompanied with increased levels of surface disturbance (e.g., through grazing) (Vitousek et al. 1997). In the Mojave Desert, a simulated deposition-level of $3.2 \mathrm{~g} \mathrm{~N} \mathrm{~m}^{-2}$ per year increased density and biomass of invasive annual plants, and decreased density and biomass of native species in a wet year (Brooks 2003).

Deposition contains approximately balanced amounts of $\mathrm{NO}_{3}{ }^{-}$and $\mathrm{NH}_{4}{ }^{+}$(Heaton et al. 1997), but these two mineral forms of $\mathrm{N}$ enter the ecosystem through different ecological pathways. Although both $\mathrm{NO}_{3}{ }^{-}$and $\mathrm{NH}_{4}{ }^{+}$are readily taken up by plants with about similar efficiency (Jackson et al. 1989; Ivans et al. 2003), microbes may have especially high affinities for $\mathrm{NH}_{4}{ }^{+}$and may preempt much of the $\mathrm{N}$ applied in this form (Jackson et al. 1989). This temporarily immobilized $\mathrm{N}$ may be released later as $\mathrm{NO}_{3}{ }^{-}$through nitrification and mineralization of microbial biomass. Biological crusts release fixed $\mathrm{N}$ chiefly as $\mathrm{NH}_{4}{ }^{+}$, which is also converted to $\mathrm{NO}_{3}{ }^{-}$by nitrifying bacteria underneath the crust, before becoming widely available to plants and other users in the ecosystem (Belnap 2002).

The timing of $\mathrm{N}$ input with respect to the growing season could also modify its effect on ecosystems, though very little is known about it to date. Biological N fixation in crusts depends on the moisture status of the crust, temperature and light intensity (Lange et al. 1998), and together, these factors constrain $\mathrm{N}$ fixation to the cooler times of the year (October to April), coinciding with the main growing season of most Colorado Plateau native plant species. By contrast, deposition$\mathrm{N}$ can be flushed into the soil with precipitation at any time of year.

The objective for this study was to assess the effects of the amount of $\mathrm{N}$ deposition, its mineral form $\left(\mathrm{NH}_{4}{ }^{+}\right.$vs. $\left.\mathrm{NO}_{3}{ }^{-}\right)$, and the timing of deposition on two dominant grasses of an arid grassland on the Colorado Plateau. We hypothesized that 1) the $\mathrm{C}_{3}$ plant Indian ricegrass (Oryzopsis bymenoides [Roemer \& J.S. Schultes] Ricker ex Piper) will respond more to $\mathrm{N}$ additions than the $\mathrm{C}_{4}$ plant galleta (Hilaria jamesii [Torr.] Benth.); 2) both species will incorporate a greater proportion of applied $\mathrm{NO}_{3}{ }^{-}$than $\mathrm{NH}_{4}{ }^{+}$, so that $\mathrm{NO}_{3}{ }^{-}$would therefore have a more immediate and possibly larger effect on plant performance than an $\mathrm{N}$-equivalent amount of $\mathrm{NH}_{4}^{+}$; and 3) the seasonal timing of $\mathrm{N}$ application will interact with the $\mathrm{N}$ use of plants; specifically, applications in spring or during a wet year (or both) should enhance leaf photosynthesis and growth more than applications during summer or in a dry year.

In addition to measuring plant water status, rates of leaf photosynthesis, aboveground growth, and the $\mathrm{N}$ content of leaves to test our hypotheses, we also measured the stable isotope ratio of leaf $\mathrm{N}$ before and after each application to assess the timing of $\mathrm{N}$ uptake. Because the applied $\mathrm{N}$ had a distinctly different $\mathrm{N}$ isotope ratio of around $0 \%$ compared to the positive isotope ratio of soil $\mathrm{N}$ (e.g., Gebauer and Ehleringer 2000), we expected that the incorporation of applied $\mathrm{N}$ into leaf tissue would be associated with a noticeable shift in the leaf $\mathrm{N}$ isotope ratio.

\section{MATERIALS AND METHODS}

\section{Study Site}

The study site, representative of a grazed Colorado Plateau bunchgrass ecosystem, was located near the Needles District entrance to Canyonlands National Park in southern Utah (lat N38.17548; long W109.72018), which is managed by the Bureau of Land Management. Vegetation cover was composed of mixed grasses and shrubs. The grass community was dominated by the spring-active annual grass downy brome (Bromus tectorum L., 75\%) and 2 native perennial grasses, Indian ricegrass $(10 \%)$ and galleta $(6 \%)$. The soil was sandy with sparse biological crust cover and little horizon development except for caliche carbonate deposits at approximately $30 \mathrm{~cm}$. The research area had been spring grazed by cattle until January 1999, when fences were erected to exclude cattle grazing for the duration of the experiment.

Within the fenced area, $203.5 \times 3.5 \mathrm{~m}$ plots were selected on the basis that they contain the 2 study species, galleta and Indian ricegrass, in sufficient quantities for repeated destructive sampling (e.g., at least 20 shoots). To prevent shallow roots from escaping the plot boundaries, edges were trenched to $20 \mathrm{~cm}$ and aluminum flashing was inserted into the trenches. Plots were then subdivided into 2 halves and also separated by flashing. The "half-plot" was the fundamental experimental unit in a split-plot design, and $\mathrm{N}$ level was controlled at the whole-plot level. 


\section{Climate Conditions}

Mean annual precipitation for the region is $215 \mathrm{~mm}$, with fairly even average rainfall distribution between months, except for June, the consistently driest month of the year, according to a 70-year record from Moab, Utah (NCDC COOP station number 425733). The mean monthly temperature ranges from $-1^{\circ} \mathrm{C}$ in January to $27^{\circ} \mathrm{C}$ in July. The two experimental years had quite contrasting rainfall conditions. According to the Needles District weather station, October to April precipitation amounted to $107 \mathrm{~mm}$ in 1998/99 (possibly underestimated due to large amounts of snowfall) and $76 \mathrm{~mm}$ in 1999/00. April to September precipitation was $195 \mathrm{~mm}$ in 1999 and $35 \mathrm{~mm}$ in 2000. Thus, the year beginning with the autumn of 1998 was at least $40 \%$ wetter than average, while the following year was $50 \%$ drier.

\section{Field Methods}

Nitrogen deposition was simulated by applying $\left(\mathrm{NH}_{4}\right)_{2} \mathrm{SO}_{4}$ in $\mathrm{KCl}$ solution or $\mathrm{KNO}_{3}$ solution along with $10 \mathrm{~mm}$ of well water at rates of $0,10,20$, and $40 \mathrm{~kg} \mathrm{ha}^{-1}$ annually, corresponding to approximately $0 \times, 1 \times, 2 \times$, and $4 \times$ an average input of $\mathrm{N}$ from atmospheric deposition (Vitousek et al. 1997). The 4 levels of $\mathrm{N}$ application were randomly assigned to the 20 plots ( 5 replicate plots per treatment). Within plots, each half-plot was randomly designated to receive $\mathrm{N}$ inputs in the form of either $\mathrm{NO}_{3}{ }^{-}-\mathrm{N}$ or $\mathrm{NH}_{4}{ }^{+}-\mathrm{N}$. To control for a possible separate effect of potassium, the fertilizer applications were supplemented with potassium chloride $(\mathrm{KCl})$ and water, so that all plots received the same amount of potassium and water. The 5 control plots (with 0 nitrogen input) received pure water on one side and $\mathrm{KCl}$ solution on the other side to test for a possible effect of potassium additions on plant performance.

The annual $\mathrm{N}$ application rate was distributed over 2 events, one in spring and one in summer. The dates of application were 19 April and 19 July 1999, and 19 April and 22 July 2000. One week before the application, plots were covered with rainexclusion shelters to safeguard against complications arising from different amounts of soil surface water at the time of fertilizer application. Shelter roofs were made of clear, corrugated polycarbonate panels (Suntuff Inc., Livingston, NJ), coated with a UV filter and $90 \%$ transparent to visible light. The $4 \times 4 \mathrm{~m}$ roofs were held up by 9 fence posts approximately $1.5 \mathrm{~m}$ off the ground with approximately $10 \%$ slant to allow rainwater to run off. The purpose of the shelters was to dry out the soil surface so that the infiltration depths of the fertilizer solutions would be similar for each application event. Rain exclusion shelters stayed in place for the subsequent 9-day observation interval to prevent possible interference by natural rain events on soil water and $\mathrm{N}$ dynamics.

On the day of fertilizer application, plants were first irrigated with $5 \mathrm{~mm}$ of well water. Then, $3 \mathrm{~L}$ of fertilizer solutions, mixed to the appropriate concentrations, were applied with hand-held sprinklers to each half-plot (equivalent to $\sim 0.5 \mathrm{~mm}$ ). Zeronitrogen control plots were sprinkled with $3 \mathrm{~L}$ of well water on one side and $3 \mathrm{~L}$ of $\mathrm{KCl}$ solution on the other. Immediately after fertilizer application, plots were watered with another $5 \mathrm{~mm}$ of water to flush the fertilizer into the soil, as well as to wash fertilizer residues from leaf surfaces.
Predawn water potentials were measured on galleta and Indian ricegrass on the days before fertilizer application and 9 days after between 0300 hours and dawn using Scholander pressure chambers. Xylem water potentials were determined on randomly selected green leaf blades.

Leaf gas exchange rates on mature leaves were determined with a portable infrared gas analyzer system (LI-6200; Li-Cor Corp, Lincoln, NE). The acquisition of a complete data set usually required 2 days. Thus, measurements were taken 2 days and 1 day before fertilizer application and on Days 1 and 2, 4, and 5, and 8 and 9, thereafter. Plots were sampled in random sequence with respect to treatment. Gas exchange rates were measured under ambient light, temperature, and humidity conditions between 0930 and 1200 hours, at the time of day when photosynthetic rates were expected to be maximal. The leaf sections for which the gas exchange rates were determined were stored in wetted coin envelopes and kept cold until leaf area determination several days later, using an LI-3100 leaf area meter (Li-Cor Corp).

Leaf $\mathrm{N}$ and $\mathrm{C}$ isotope composition was determined by an isotope ratio mass spectrometer (Delta S; Finnigan MAT, San José, CA). Random samples of mature leaves from several locations in the plot area were taken 2 days before fertilizer application and on Days 1, 4, and 8 thereafter. Samples were dried at $70^{\circ} \mathrm{C}$ and ground to a fine powder. Subsamples $(2 \mathrm{mg})$ were inserted into the combustion chamber of a Carla Erba elemental analyzer (Milan, Italy), connected to the mass spectrometer operating in continuous flow mode. Nitrogen isotope ratios were expressed in $\delta$ notation as parts per thousand $(\%)$ :

$$
\delta=\left(\frac{\mathrm{R}_{\text {sample }}}{\mathrm{R}_{\text {standard }}}-1\right) \cdot 1000 \%
$$

where $R$ is the molar ratio of heavy to light isotopes $\left({ }^{15} \mathrm{~N} /{ }^{14} \mathrm{~N}\right)$. The standards were atmospheric $\mathrm{N}$.

On 20 July 2000, soil cores were extracted to determine gravimetric soil water content in $10-\mathrm{cm}$ intervals down to a depth of $50 \mathrm{~cm}$. Soil samples were weighed before and after drying for 24 hours at $90^{\circ} \mathrm{C}$.

In mid-April of both years, just before the pulse application, 5 randomly selected tillers of each species were marked in every half-plot with plastic coated wire. Stem length and total leaf blade length of the marked tillers were measured repeatedly, up to 4 times per year, distinguishing between green and senescent leaf blade fractions. Total blade length was taken as a proxy for leaf biomass, as regression analysis suggested a reasonably strong linear correlation between the 2 measures $\left(r^{2}=0.93\right.$ for Indian ricegrass, 0.80 for galleta). Only the average (i.e., within the half-plot) per tiller green leaf blade length was used in the statistical analysis.

In the second year of the experiment, we realized that the analysis of individual tiller growth did not adequately represent all growth responses to fertilization, and added an area-based estimate of biomass. In May 2000, we measured the length and width of all Indian ricegrass tussocks within the half-plot areas and visually estimated the fraction of green tillers within each tussock. We then multiplied estimated live fraction and tussock area to determine live tussock area. The sum of this measure divided by the plot area was then taken as a proxy for live 
Table 1. Mean predawn water potentials (MPa) just before and 9 days after each fertilizer application.

\begin{tabular}{lcc}
\hline Date & Galleta (SD) & Indian ricegrass (SD) \\
\hline 17 April 1999 (before) & $-0.62(0.17)$ & $-0.64(0.17)$ \\
28 April 1999 (9 days after) & $-0.97(0.33)$ & $-0.94(0.27)$ \\
17 July 1999 (before) & $-1.18(0.53)$ & $-1.89(0.58)$ \\
28 July 1999 (9 days after) & $-2.90(1.03)$ & $-2.96(0.78)$ \\
13 April 2000 (before) & $-0.71(0.28)$ & $-0.62(0.20)$ \\
14 April 2000 (9 days after) & $-0.55(0.19)$ & $-0.71(0.21)$ \\
20 July 2000 (before) & $-4.32(1.04)$ & $-4.47(0.81)$ \\
30 July 2000 (9 days after) ${ }^{1}$ & $-4.52(0.96)$ & $-4.60(1.17)$ \\
\hline
\end{tabular}

${ }^{1}$ All treatment effects on water potentials were insignificant except on 30 July 2000.

biomass density. Galleta does not form tussocks, so we counted live tillers within randomly selected quarter-plots, and tiller density was taken as a proxy for biomass density.

In the first year of the study, we noticed the rapid growth of the invader Russian Thistle (Salsola iberica, Sennen \& Pau), particularly in N-fertilized plots, and decided to remove it from all plots to maintain the experimental focus on the 2 grass species. Shoots were removed just before seed set on 30 August 1999 , followed by the determination of stem number and dry weight.

The statistical analyses were based on a repeated measures analysis of variance (ANOVA) with $\mathrm{N}$ form $\left(\mathrm{NH}_{4}{ }^{+}\right.$or $\left.\mathrm{NO}_{3}{ }^{-}\right)$ as the within-subject factor and $\mathrm{N}$ level $(0,10,20$, and $40 \mathrm{~kg} \mathrm{~N}$ $\mathrm{ha}^{-1}$ ) as the between-subject factor. Because there was no statistical difference between the 2 no-nitrogen half-plots (treated with well water or $\mathrm{KCl}$ solution), we arbitrarily grouped the pure water side of control plots with the $\mathrm{NH}_{4}{ }^{+}$ set and the potassium side of control plots with the $\mathrm{NO}_{3}{ }^{-}$ set. Variables were either not transformed or log-transformed to pass the Box M Test for equality of variance-covariance across cells formed by the between-subject effects (SPSS Inc. 1999). Transformed variables did not generally satisfy the sphericity assumption of repeated ANOVA, so we used the lower-bound epsilon (i.e., the most conservative method) to adjust the degrees of freedom in the significance test (SPSS Inc. 1999).

\section{RESULTS}

\section{Short-Term Physiological Responses to Water and Nitrogen Pulses}

In all instances, the 10 -mm water application was not sufficient to significantly increase leaf conductance and photosynthesis on the day after the $\mathrm{N}$ application above the levels measured the day(s) before the application $(P>0.05$, data not shown). In spring, plants were apparently not water-limited, as predawn water potentials were greater than $-1 \mathrm{MPa}$ both at the beginning and at the end of the 10-day observation period (Table 1). Conditions at the beginning of the summer application in 1999 were slightly drier, and predawn water potentials $\left(\Psi_{\text {predawn }}\right)$ dropped by about $1 \mathrm{MPa}$ over 10 days. By contrast, plants were extremely water-stressed in the summer of 2000, when both grass species had average predawn water potentials $<-4 \mathrm{MPa}$ before application.
The mineral form in which $\mathrm{N}$ was supplied (in short: $\mathrm{N}$ form) had no significant effect on $\Psi_{\text {predawn, leaf conductance or }}$ the photosynthetic rates of the two grass species $(P>0.1$ in all instances). The level of $\mathrm{N}$ fertilization (in short: $\mathrm{N}$-level) also had no significant effects on these variables on most measurement dates, but there were 2 exceptions: In the summer of 1999, the leaf conductance of Indian ricegrass on the days immediately following the fertilizer application was significantly affected by N-level $(P=0.002)$, with higher leaf conductance in plots fertilized with 0 and $10 \mathrm{~N} \mathrm{~kg} \mathrm{ha}^{-1}$ than with 20 and $40 \mathrm{~kg} \mathrm{~N}^{-1}$ (data not shown). A similar effect was recorded in the dry summer of 2000 (Fig. 1), when $\Psi_{\text {predawn }}$ of Indian ricegrass on the days before fertilizer application was significantly less negative in nonfertilized control plots, compared to all fertilized plots $(P=0.014)$. In both species, leaf conductance (Indian ricegrass, $P=0.024$; galleta, $P=0.006$ ) and photosynthesis rates (Indian ricegrass, $P=0.034$; galleta, $P=0.020)$ were significantly higher in control plots on the days immediately following the fertilizer application. On some of the subsequent days, there were also either significant or marginally significant effects of $\mathrm{N}$-level on photosynthesis for the 2 species.

The effects of $\mathrm{N}$ fertilization on plant water status were mediated by differences in soil water status: Plots receiving no fertilizer were wetter below $30 \mathrm{~cm}$ than plots receiving any amount of fertilizer (Fig. 2). This suggests that the rates of plant water extraction from late spring to midsummer must have been greater in fertilized plots, thus accelerating the development of plant water stress.

\section{Fertilizer Effects on Leaf Nitrogen Content and Isotope Ratios}

In both species, leaf $\mathrm{N}$ concentrations (as mass \%) were generally higher in spring than in summer (Fig. 3). Leaf $\mathrm{N}$ content was not significantly affected by $\mathrm{N}$-form $(P>0.1)$, but beginning with the summer pulse in 1999, plants in fertilized plots tended to have higher leaf $\mathrm{N}$ content. However, the effect of $\mathrm{N}$-level on leaf $\mathrm{N}$ content was generally secondary to the magnitude of seasonal fluctuation (Fig. 4).

Beginning with the summer of $1999, \mathrm{~N}$-form had strong effects on the stable isotope ratio of leaf $\mathrm{N}$ (leaf $\delta^{15} \mathrm{~N}$ ) $(P<0.05$; Fig. 5), though the main effect of $\mathrm{N}$-level on leaf $\delta^{15} \mathrm{~N}$ was not significant $(P>0.05)$. In most cases there was also a significant interaction between $\mathrm{N}$-level and $\mathrm{N}$-form $(P<0.05$, except galleta in summer 1999 , with $P=0.064)$. In $\mathrm{NH}_{4}{ }^{+}$-fertilized plots, leaf $\delta^{15} \mathrm{~N}$ increased with $\mathrm{N}$-level, whereas there was a slight decline toward $0 \%$ (the isotope ratio of the fertilizer) in $\mathrm{NO}_{3}{ }^{-}$-fertilized plots. These trends were very similar in the two species, suggesting that 1) soil processes were responsible for changing the isotope ratios of plantavailable $\mathrm{N}$ across the $\mathrm{N}$ treatments, rather than fractionation associated with nitrogen uptake, metabolism, or redistribution; and 2) the 2 species used nearly identical $\mathrm{N}$ sources throughout the experiment and across treatments.

\section{Growth}

There were no significant effects of N-level or N-form on the growth of individual tillers in $1999(P>0.1$; data not shown) or 2000 (Fig. 6; $P>0.1$ ). However, in the spring of 2000, 


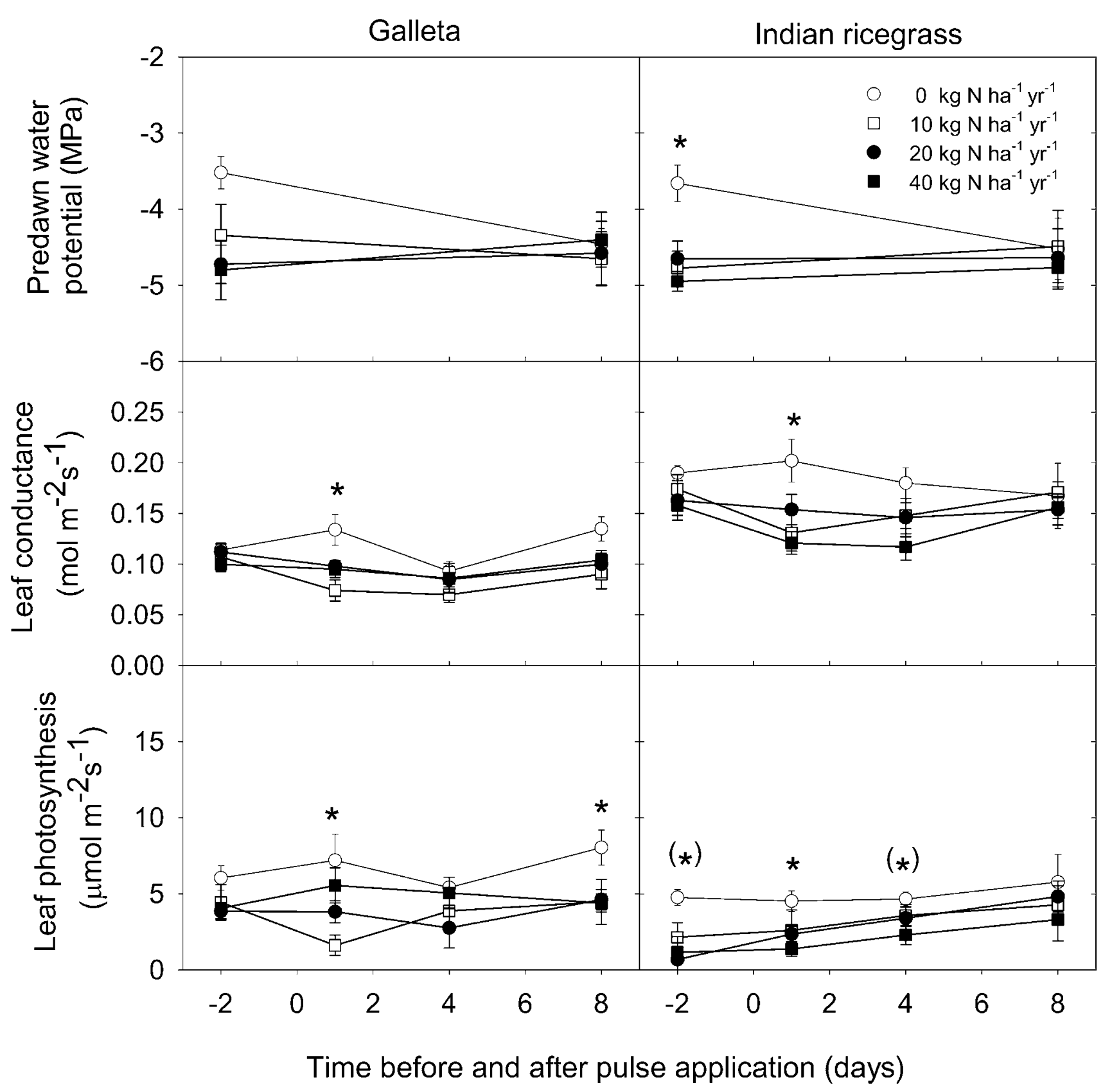

Figure 1. Predawn water potentials, leaf conductance, and leaf photosynthesis over the 10-day observation period between $20-30$ July 2000. Data sets were collected over 2-day intervals but are represented in this graph by the starting date of the measurement. Error bars represent standard errors of the mean. * Indicates a significant effect of nitrogen level at the 0.05 level. $\left({ }^{*}\right)$ indicates a marginally significant effect $(0.05<P<$ 0.1). N-form had no significant effects.

we estimated a $50 \%$ greater live area cover for Indian ricegrass at 20 and $40 \mathrm{~kg} \mathrm{~N} \mathrm{ha}^{-1}$, compared to the 0 and $10 \mathrm{~kg} \mathrm{~N}$ nitrogen ha $\mathrm{h}^{-1}$ application level (Fig. 7). By contrast, we detected no significant differences among treatments in the shoot density of galleta. However, shoot density was more spatially variable in galleta than in Indian ricegrass.

\section{Invasion by Russian Thistle}

In 1999, when rapid growth of Russian thistle was observed in the experimental plots, the stem density of Russian thistle was not significantly affected by $\mathrm{N}$-level $(P=0.696)$ or $\mathrm{N}$-form $(P=0.884)$, but shoot biomass was significantly affected by
N-level $(P<0.001)$, N-form $(P=0.009)$, as well as their interaction $(P=0.01)$. Specifically, the dose effect of $\mathrm{NO}_{3}{ }^{-}$ outweighed the dose-effect of $\mathrm{NH}_{4}{ }^{+}$(Fig. 8).

\section{DISCUSSION}

\section{N-Level Effects}

This study showed that the two main native forage grasses on this Colorado Plateau rangeland were similar in their ability to incorporate mineral $\mathrm{N}$ deposited to the soil surface, although they apparently differed in its use. Changes in leaf $\delta^{15} \mathrm{~N}$ clearly indicated that the added $\mathrm{N}$ was incorporated, if not immedi- 


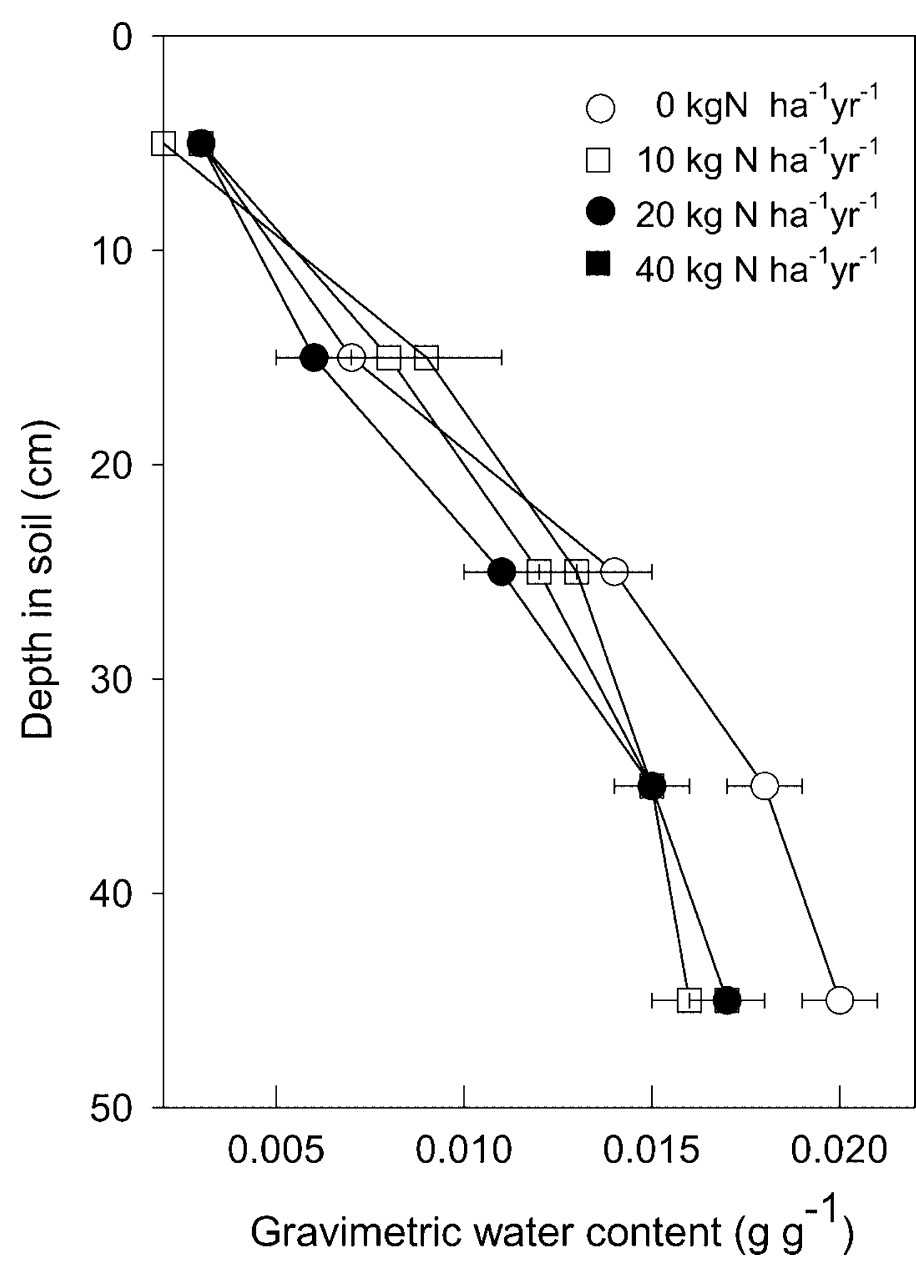

Figure 2. Soil water content profile taken to a depth of $50 \mathrm{~cm}$ in $10-\mathrm{cm}$ increments on 20 July 2000, 2 days before pulse application. Error bars represent standard errors of the mean.

ately, within at most 3 months of the first $\mathrm{N}$ application (Fig. 6). However, at least $20 \mathrm{~kg} \mathrm{~N} \mathrm{ha}^{-1}$ annually was required to significantly increase leaf $\mathrm{N}$ levels (Fig. 3). Even so, increased leaf $\mathrm{N}$ content did not increase leaf assimilation rates in either species.

The $\mathrm{C}_{3}$ plant Indian ricegrass increased growth at an application rate of $\geq 20 \mathrm{~kg} \mathrm{~N} \mathrm{ha}^{-1}$ annually (Fig. 7), although this was expressed only at the genet level and not at the level of individual tillers (Fig. 6). The $\mathrm{C}_{4}$ grass galleta showed no detectable growth responses to increased $\mathrm{N}$ levels at the genet or tiller level. Although it is possible that $\mathrm{N}$ fertilization may have affected belowground rhizome proliferation in galleta, which would have gone undetected in the first year of the study, this should have eventually led to increased aboveground growth and become detectable in the second year. Because we found neither short- nor long-term effects of $\mathrm{N}$ fertilization on tiller growth or number in galleta, it is likely that this species did not benefit from $\mathrm{N}$ fertilization to the same extent as Indian ricegrass. This supported our initial hypothesis that the $\mathrm{C}_{4}$ grass should respond less to $\mathrm{N}$ inputs than the $\mathrm{C}_{3}$ grass.

The mechanism widely held responsible for making $\mathrm{C}_{3}$ plants more responsive to soil $\mathrm{N}$ inputs is their relatively low photosynthetic $\mathrm{N}$ use efficiency, which limits their photosynthetic capacity with respect to $\mathrm{C}_{4}$ plants at low $\mathrm{N}$ levels in soil, but less

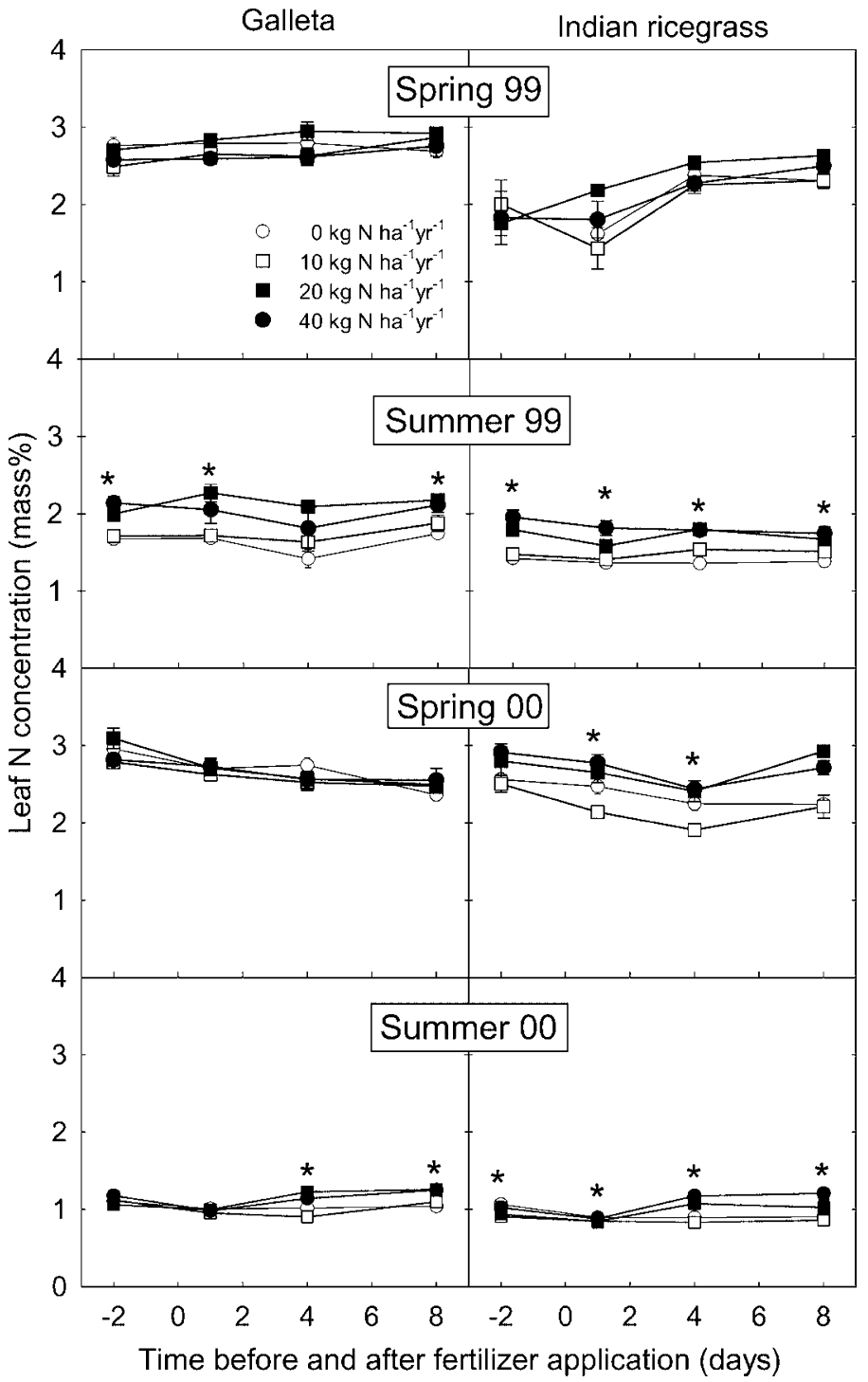

Figure 3. Leaf $\mathrm{N}$ content, averaged over $\mathrm{N}$-form, between 2 days before and 8 days after pulse application. Error bars represent standard errors of the mean. ${ }^{*}$ Indicates a significant effect of $\mathrm{N}$-level at the 0.05 level.

so at high N levels in soil (Brown 1978; Sage and Pearcy 1987; Sage and Kubien 2003). Both species in our study increased the leaf $\mathrm{N}$ concentration at the highest application level (Fig. 4), but contrary to expectation, photosynthetic rates were not increased in either species (Fig. 1). This casts doubt on whether the difference in the photosynthetic pathways of the 2 grasses was really the decisive factor for differences in the growth responses to $\mathrm{N}$ input. In another $\mathrm{C}_{3} / \mathrm{C}_{4}$ comparison in a short-grass prairie, simulated ungulate-urine deposition increased the tiller density of both species (Jarmillo and Detling 1992), but with different time lags between application and growth response. Differences in the species' autecology, not strongly tied to the type of photosynthetic pathway, determined their fertilizer responses. Rangeland species typically vary in their responses to soil $\mathrm{N}$ (Lowe et al. 2002). In this study, galleta was the more shallowrooted of the 2 species, and is known to respond more strongly to fluctuations in the soil water content within centimeters of the soil surface (Schwinning et al. 2003). Thus, it is possible that 


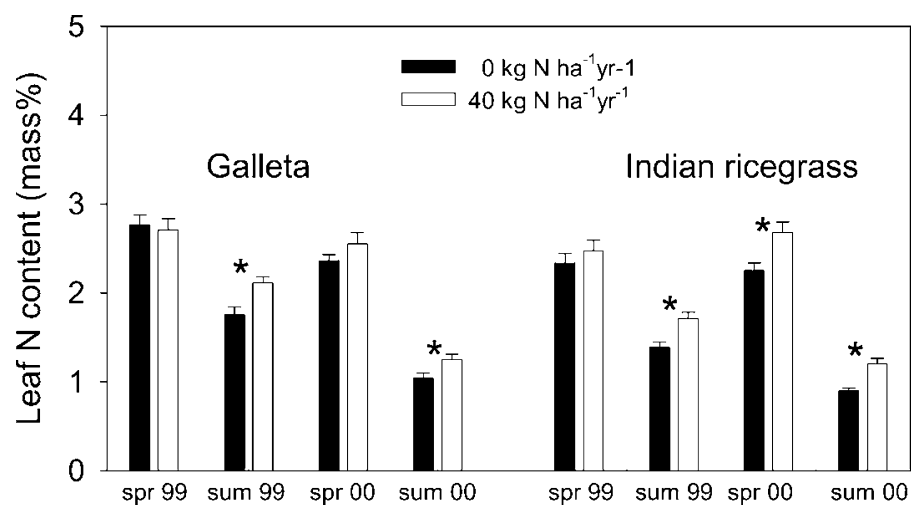

Figure 4. Comparison of seasonal vs. fertilizer effects on leaf $N$, as measured 8 days after application. *Indicates a significant effect of $\mathrm{N}$-level at the 0.05 level.

growth in galleta is more frequently limited by water (thus carbon), and less by $\mathrm{N}$ compared to Indian ricegrass.

Although spring growth of Indian ricegrass was enhanced by fertilization in 2000 , this also led to an earlier onset of water stress in a year with a $50 \%$ drier than average winter/spring period. Galleta, lacking a positive growth response, was only negatively affected by fertilizer application (Fig. 1).

By far the greatest growth response in this experiment occurred in the invader Russian thistle between July and August of the first year, when summer precipitation was $80 \%$ above average. This was not a response that we anticipated, because at the time the experiment was planned, there was no obvious intrusion of invasive species in the plot area. Nevertheless, we learned from this unplanned experiment that the combination of high $\mathrm{N}$ and high water availability at the time of peak growth activity for this species elicited rapid vegetative growth, in contrast to the 2 native grasses, which had already completed spring growth and were apparently unable to take advantage of the increased resource supply in July. Another study conducted on the same site in the same year also indicated that growth in Colorado Plateau native perennials, including Indian ricegrass, were quite insensitive to variation in summer rainfall (Schwinning et al. 2005).

As Adams (2003) pointed out in a recent review of $\mathrm{N}$ effects in natural ecosystems, fertilization studies in arid ecosystems are extremely rare. The most closely related study we were able to identify was a fertilization experiment in the Mojave Desert (Brooks 2003). The $\mathrm{N}$ application rate in this study was $32 \mathrm{~kg}$ $\mathrm{N} \mathrm{ha}{ }^{-1}$ annually over 2 years, thus within the range of application rates used in this study and above what we identified as the response threshold for growth effects in Indian ricegrass (Fig. 7). Despite the obvious differences in these 2 ecosystems (e.g., in average temperature and seasonal rainfall patterns), the conclusions from the Mojave study were remarkably similar. In both studies, alien annual invaders benefited more from fertilizer inputs than resident species and the input likely enhanced competition for soil water.

\section{N-Form Effects}

We hypothesized that the two grasses should be more responsive to $\mathrm{N}$ applications in the form of $\mathrm{NO}_{3}{ }^{-}$than $\mathrm{NH}_{4}{ }^{+}$, because $\mathrm{NH}_{4}{ }^{+}$is more rapidly taken up by microbes than by

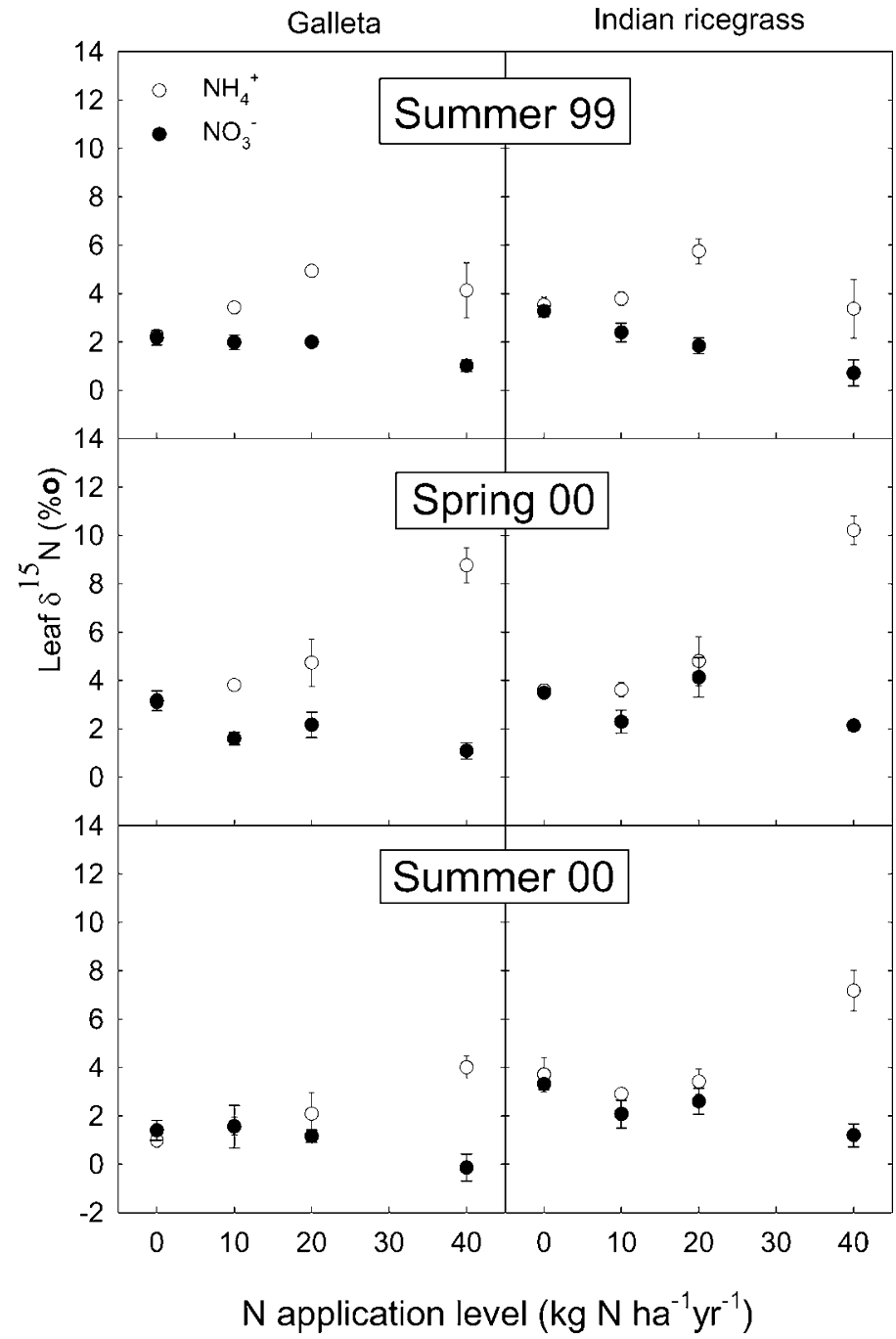

Figure 5. Dose responses of leaf N stable isotope ratios to N-level. Data points represent the means of the observation interval. Error bars represent standard errors of the mean of the time averages. See text for results of the significance tests.

plants (Jackson et al. 1989). In this study, N-form did not affect the performance of the 2 native grasses. However, Russian thistle did respond more strongly to $\mathrm{NO}_{3}{ }^{-}$than to $\mathrm{NH}_{4}{ }^{+}$(Fig. 8 ), suggesting that, at least in summer, a substantial fraction of the applied $\mathrm{NH}_{4}{ }^{+}$was immobilized by soil microbes. While the summer rain events of 1999 may have allowed microbes to incorporate $\mathrm{NH}_{4}^{+}$, the rapid drying of the soil surface thereafter may have slowed nitrification, which is inhibited by low soil moisture (Mazzarino et al. 1998), until autumn. Such a shift in the ecosystem use of applied $\mathrm{NH}_{4}{ }^{+}$, from immobilization in summer to nitrification in autumn-to-spring, would explain why the warm-season species in this study was responsive to $\mathrm{N}$ form, while the 2 cold season species were not.

There was isotopic evidence that applied $\mathrm{NO}_{3}{ }^{-}$and $\mathrm{NH}_{4}{ }^{+}$ entered the ecosystem through different metabolic pathways. Leaf $\mathrm{N}$ was far more enriched when plots were fertilized with $\mathrm{NH}_{4}{ }^{+}$than with $\mathrm{NO}_{3}{ }^{-}$(Fig. 5). This enrichment could have occurred through microbial conversion of $\mathrm{NH}_{4}^{+}$into $\mathrm{NO}_{3}{ }^{-}$. Alternatively, there could have been differential isotope dis- 


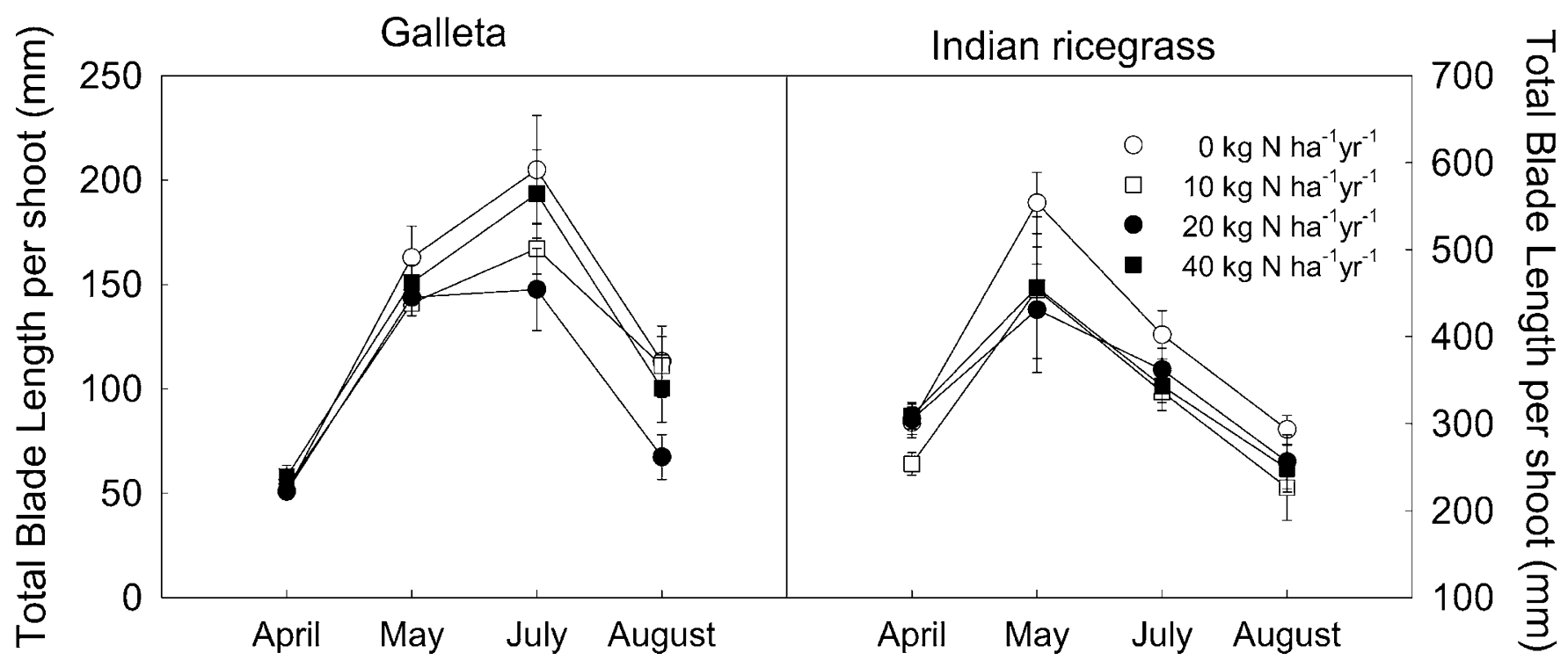

Figure 6. Total leaf blade length of tillers on 4 measurement dates in 2000 . N-form and N-level had no significant effects.

crimination for $\mathrm{NH}_{4}{ }^{+}$into $\mathrm{NO}_{3}{ }^{-}$by the plant. There is still much uncertainty about the degree of isotope discrimination during the uptake, assimilation, and partitioning of $\mathrm{NO}_{3}{ }^{-}$and $\mathrm{NH}_{4}{ }^{+}$, particularly when the substrate supply is finite (Robinson 2001). A third explanation is that soil $\mathrm{NH}_{4}{ }^{+}$may have become enriched through volatilization. Estimates of fractionation associated with volatilization range from $40 \%$ to $60 \%$ (Robinson 2001), thus are consistent with the magnitude of the observed leaf $\mathrm{N}$ enrichment (Fig. 5). However, volatilization rates are probably quite low in this ecosystem (Barger 2003), and for residual $\mathrm{NH}_{4}{ }^{+}$to become so highly enriched, a large fraction of the $\mathrm{NH}_{4}{ }^{+}$pool would have to be lost by volatilization, which is inconsistent with the lack of an $\mathrm{N}$-form effect on leaf $\mathrm{N}$ content. Thus, the most parsimonious explanation for the observed leaf $\mathrm{N}$ enrichment patterns is that the $\mathrm{NH}_{4}{ }^{+}$-fertilized grasses incorporated enriched $\mathrm{NO}_{3}{ }^{-}$released from microbes after nitrification, most likely in autumn to spring.

\section{Effects of the Timing of Application}

Our third and last hypothesis was that the timing of fertilizer application, especially in relation to seasonal and interannual changes in soil water availability, should affect the $\mathrm{N}$ use of plants. In hindsight, this hypothesis was too simplistic by several accounts. First, the lack of a short-term effect of $\mathrm{N}$ application, for example on photosynthetic rates, did not allow us to compare effects of spring and summer application on plant performance. Furthermore, both species grew only in

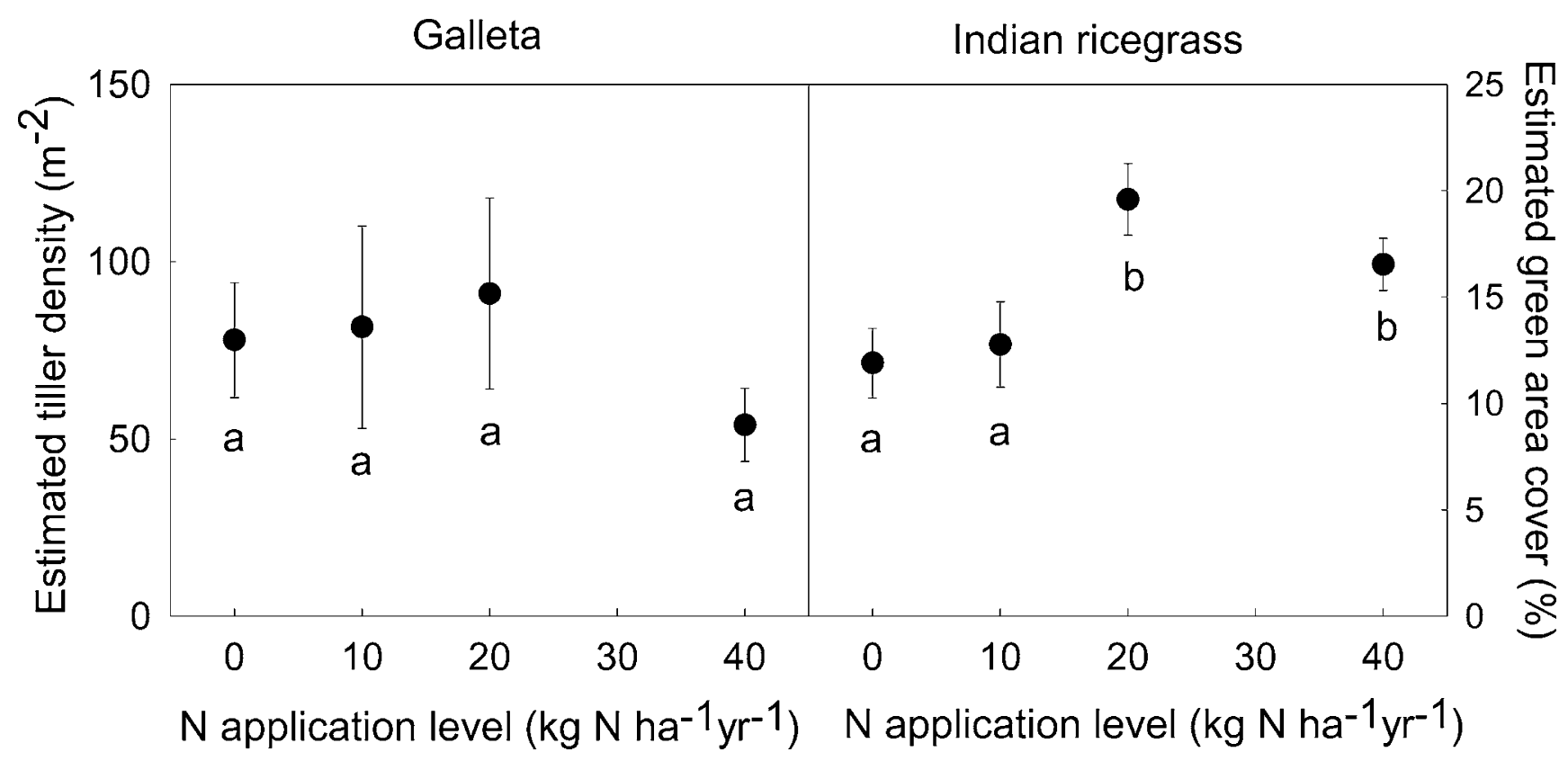

Figure 7. Estimates of tiller density taken on 2 May 2000. Same letters indicate no significant differences at the 0.05 level. 
spring and not in summer, making it impossible to distinguish the effects of spring and summer applications on growth. Comparisons between years were also limited because most plant performance measures were insensitive to $\mathrm{N}$ inputs. We can, however, say that the negative effect of $\mathrm{N}$ fertilization on the water status of the two grasses in summer were stronger in the drier of the 2 years, suggesting that the negative feedback of $\mathrm{N}$ fertilization on plant water status, presumably through increased plant growth and evapotranspiration, is enhanced or accelerated in a dry year. Second, the mass germination of Russian thistle occurred only in the year with higher than average summer rainfall, suggesting that $\mathrm{N}$ fertilization affects the more ephemeral species such as Russian thistle only in wet years that foster high germination rates.

It is well known that not just the amount but also the timing of $\mathrm{N}$ deposition is paramount to determining its effect in this grassland community. This study showed that deposition in summer potentially benefits summer active weedy invaders more than native species. Nitrogen deposition from autumn to spring increases the growth rates of some native grasses, but this benefit may be curbed substantially by an accelerated onset of water stress in early summer. Increases in the $\mathrm{N}$ deposition rate could thus shift the competitive balance among the native flora toward those species that flower and set seed earlier.

\section{CONCLUSION}

In the introduction, we posed the question whether $\mathrm{N}$ deposition in the Colorado Plateau ecosystem could today, or some time in the future, substitute for reduced $\mathrm{N}$ inputs from cryptobiotic crusts. Current estimates of $\mathrm{N}$ inputs from $\mathrm{N}$ fixation from disturbed desert areas, representative of grazed conditions, range from 0 to $1.4 \mathrm{~kg} \mathrm{~N} \mathrm{ha}^{-1}$ annually (Belnap 2002). This is in contrast with the rates estimated for welldeveloped undisturbed sites, representative of historic pregrazing conditions, which range from 9 to $13 \mathrm{~kg}$ of $\mathrm{N}$ per ha $\mathrm{ha}^{-1}$ annually (Belnap 2002). Wet deposition levels near the study site are currently around $1.0 \mathrm{~kg}$ of $\mathrm{N}$ per ha ${ }^{-1}$ (National Atmospheric Deposition Program [NRSP-3] 2005), and dry deposition may be of the same magnitude. Thus, current levels of deposition rival those of inputs of $\mathrm{N}$ fixation on grazed land and, if the increasing trend continues, may become closer to historic levels in the future.

However, the annual dynamics of soil $\mathrm{N}$ turnover are likely to be very different. Nitrogen inputs from dry or wet deposition are as likely to occur during the main growing season of the native Colorado Plateau vegetation from March through May (Comstock and Ehleringer 1992) as during the summer monsoon season, when native plants are fairly inactive and unresponsive to rain (Schwinning et al. 2003, 2005), but annual invaders from summer-active regions can grow rapidly, as seen in this experiment.

By contrast, biological crusts are active only during the cooler months, from autumn to spring, when they release fixed $\mathrm{N}$ to the surrounding soil first as $\mathrm{NH}_{4}{ }^{+}$, which is then rapidly transformed to $\mathrm{NO}_{3}{ }^{-}$by microbial associates (Belnap 2003). Thus, the N-fertilization effect of crust coincides with the time of maximum $\mathrm{N}$ demand in the native vegetation, while $\mathrm{N}$ fixation is negligible and crusts tend to lose $\mathrm{N}$ in gaseous form

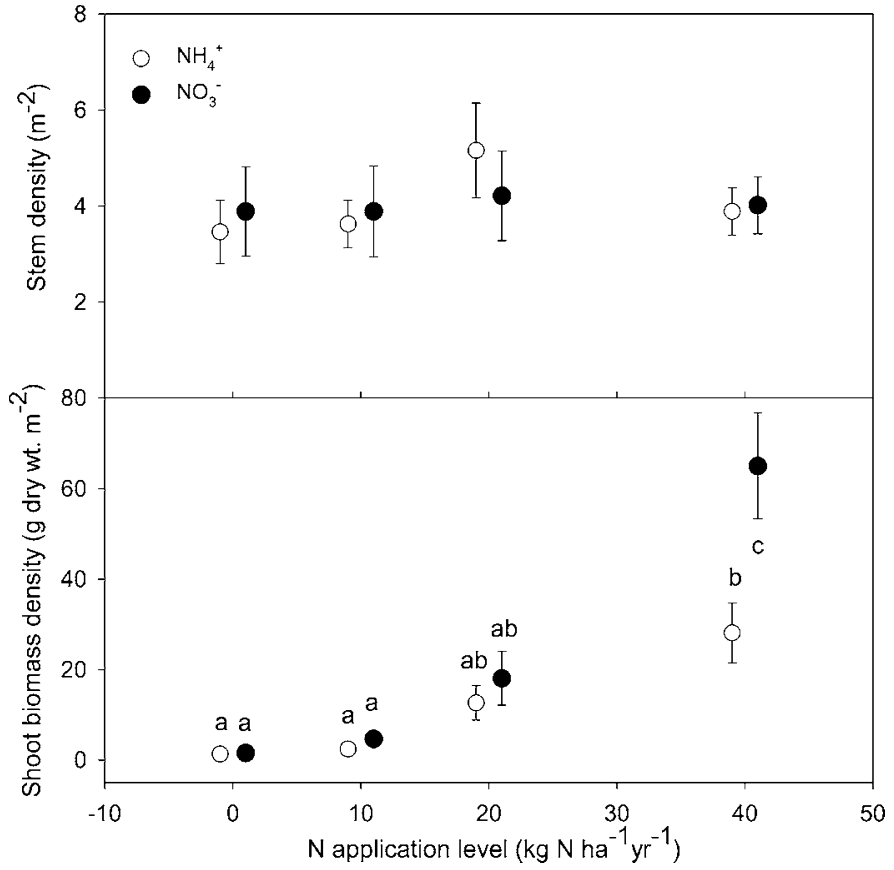

Figure 8. Dose response of Russian thistle stem density and aboveground biomass density to N-level. Plants were harvested on 30 August 1999. Same letters indicate no significant differences at the 0.05 level.

during summer. This close coupling between the $\mathrm{N}$ release by crusts and the peak $\mathrm{N}$ demand in native plant species may have maintained native grasslands before the introduction of cattle grazing and kept the invasion of summer-active flora at bay despite the occurrence of summer rains. Today, the simultaneous decline of crust cover and increase in $\mathrm{N}$ deposition may have weakened the resilience of this ecosystem to change and increased its vulnerability to invasion by weedy summer annuals. While native vegetation and biological crusts coevolved for thousands of years, native species may be increasingly maladapted to the new dominant source of ecosystem $\mathrm{N}$ inputs. To maintain desirable native forage grasses in this ecosystem in the long run, it may be necessary to protect biological crusts and encourage their recovery through reduced grazing.

\section{LITERATURE CITED}

Adams, M. B. 2003. Ecological issues related to $\mathrm{N}$ deposition in natural ecosystems: research needs. Environment International 29:189-199.

Barger, N. N. 2003. Biogeochemical cycling and N dynamics of biological soil crusts in a semi-arid ecosystem [dissertation]. Fort Collins, CO: Colorado State University. $131 \mathrm{p}$.

BelnaP, J. 2002. Nitrogen fixation in biological soil crusts from southeast Utah, USA. Biology and Fertility of Soils 35:128-135.

BELNAP, J. 2003. Factors influencing nitrogen fixation and nitrogen release in biological soil crusts. In: J. Belnap and 0. L. Lange [EDS.]. Biological Soil Crusts: Structure, Function and Management. Berlin, Germany: Springer Verlag. p 241-261.

BRooks, M. L. 2003. Effects of increased soil nitrogen on the dominance of alien annual plants in the Mojave Desert. Journal of Applied Ecology 40:344-353.

Brown, R. H. 1978. A difference in $\mathrm{N}$ use efficiency in $\mathrm{C}_{3}$ and $\mathrm{C}_{4}$ plants and its implications in adaptation and evolution. Crop Science 18:93-98.

Comstock, J. P., And J. R. Ehleringer. 1992. Plant adaptation in the Great Basin and Colorado Plateau. Great-Basin-Naturalist 52:195-215. 
EhleRingeR, J. R. 2001. The productivity of Deserts. In: J. Roy, B. Saugier, and H. A. Mooney [EDS.]. Terrestrial Global Productivity. San Diego, CA: Academic Press. p 345-362.

Evans, R. D., AND J. Belnap. 1999. Long-term consequences of disturbance on nitrogen dynamics in an arid ecosystem. Ecology 80:150-160.

Gebauer, R. L. E., AND J. R. Ehleringer. 2000. Water and nitrogen uptake patterns following moisture pulses in a cold desert community. Ecology 81:1415-1424.

Heaton, T. H. E., B. Spiro, S. Madeline, and C. Robertson. 1997. Potential canopy influences on the isotopic composition of nitrogen and sulphur in atmospheric deposition. Oecologia 109:600-607.

HigGins, R. W., AND W. SHI. 2000. Dominant factors responsible for interannual variability of the summer monsoon in the southwestern United States. Journal of Climate 13:759-776.

HoOpeR, D. U., AND L. Johnson. 1999. Nitrogen limitation in dryland ecosystems: responses to geographical and temporal variation in precipitation. Biogeochemistry 56:247-293.

Ivans, C. Y., A. J. Leffler, U. Spaulding, J. M. Stark, R. J. Ryel, and M. M. Caldwell. 2003. Root responses and nitrogen acquisition by Artemisia tridentata and Agropyron desertorum following small summer rainfall events. Oecologia 134:317-324.

JaCKSON, L. E., J. P. SChimel, AND M. K. FiRestone. 1989. Short-term partitioning of ammonium and nitrate between plants and microbes in an annual grassland. Soil Biology \& Biochemistry 21:409-415.

Jarmillo, V. J., AND J. K. DetLing. 1992. Small-scale heterogeneity in a semi-arid North American grassland. I. Tillering, $\mathrm{N}$ uptake and retranslocation in simulated urine patches. Journal of Applied Ecology 29:1-8.

Lange, 0. L., J. Belnap, and H. Reichenberger. 1998. Photosynthesis of the cyanobacterial soil-crust lichen Collema tenax from arid lands in southern Utah, USA: role of water content on light and temperature responses of $\mathrm{CO}_{2}$ exchange. Functional Ecology 12:195-202.

Lowe, P. N., W. K. Lauenroth, AND I. C. BuRKe. 2002. Effects of nitrogen availability on the growth of native grasses and exotic weeds. Journal of Range Management 55:94-98.
Mazzarino, M. J., M. B. Bertiller, C. Sain, P. Satti, and F. Coronato. 1998. Soil nitrogen dynamics in northeastern Patagonia steppe under different precipitation regimes. Plant and Soil 202:125-131.

Nash, T. H., AND L. L. Sigal. 1999. Epiphytic lichens in the San Bernardino mountains in relation to oxidant gradients. In: P. R. Miller and J. R. McBride [EDS.]. Oxidant air pollution impacts on the montane forests of Southern California: A case study of the San Bernardino Mountains. Ecological Studies 134. New York, NY: Springer-Verlag. p 223-234.

National Atmospheric Deposition Program (NRSP-3) 2005.NAdP Program Office, Illinois State Water Survey, 2204 Griffith Dr., Champaign, IL 61820.

RoBinson, D. 2001. Delta N-15 as an integrator of the nitrogen cycle. Trends in Ecology and Evolution 16:153-162.

Sage, R. F., and R. W. Pearcy. 1987. The nitrogen use efficiency of $C_{3}$ and $C_{4}$ plants: I. Leaf nitrogen, growth, and biomass partitioning in Chenopodium album (L.) and Amaranthus retroflexus (L.). Plant Physiology 84:945-958.

Sage, R. F. and D. S. KuBien. 2003. Quo vadis $\mathrm{C}_{4}$ ? An ecophysiological perspective on global change and the future of $\mathrm{C}_{4}$ plants. Photosynthesis Research 77:209-225.

Schwinning, S., B. I. StarR, AND J. R. Ehleringer. 2003. Dominant cold desert plants do not partition warm season precipitation by event size. Oecologia 136: 252-260.

Schwinning, S., B. I. Starr, and J. R. Ehleringer. 2005. Effects of summer and winter drought on a Colorado Plateau grass/shrub system. II: effects on carbon assimilation and growth. Journal of Arid Environments 61:61-78.

SPSS Inc. 1999. SPSS Advanced Models 10.0. Chicago, IL: SPSS Inc. 333 p.

Vitousek, P. M., J. D. Aber, R. W. Howarth, G. E. Likens, P. A. Matson, D. W. SCHIndLeR, W. H. Schlesinger, and D. G. Tilman. 1997. Human alteration of the global nitrogen cycle: sources and consequences. Ecological Applications 7:737-750.

Wedin, D. A., and D. Tilman. 1996. Influence of nitrogen loading and species composition on the carbon balance of grasslands. Science 274: $1720-1723$. 